\title{
$\mathrm{Q}$ 방법론을 이용한 일본식 건물군의 근대문화유산 가치에 관한 인식 연구 \\ - 서울시 후암도을 중심으로 -
}

박한솔* · 성종상**

"서울대학교 대학원 협동과정 조경학 박사과정·"서울대학교 환경대학원 환경조경학과 교수

\section{A Study on the Recognition of Modern Cultural Heritage Value of Japanese-style Building Groups Using Q Methodology - Focusing on Huam-dong, Seoul -}

\author{
Park, Han-Sol ${ }^{*}$ Sung, Jong-Sang ${ }^{*}$ \\ "Ph.D. Candidate, Interdisciplinary Program in Landscape Architecture, Seoul National University \\ "Professor, Graduate School of Environmental Studies, Seoul National University
}

\begin{abstract}
Huam-dong is a representative area from the Japanese colonial period and is the space where most Japanese-style buildings remain in Seoul. Interest in modern cultural heritage continues to increase, including the registration of cultural properties in 2001, building assets in 2015, and the registration of cultural property units in 2018. As the debate continues over the necessity of preserving cultural heritage that reminds us of the Japanese colonial, there is a need for research to grasp the perceptions of stakeholders along with the perceived value of such spaces. This study identified the subjective perception types of the stakeholders concerned with the Japanese-style building group in Huam-dong, analyzed characteristics by types, and debated the issues. For this purpose, $\mathrm{Q}$ methodology, which is a statistical technique for measuring human self-subjectivity and extracting common human perspectives, was used. A literature study on the values of Huam-dong and modern cultural heritage was conducted, and a Q questionnaire based on five aspects of modern cultural heritage values (historical, architectural, sociocultural, landscape, and economic) was applied. The results of the study depicted three types of cognition and showed different attitudes toward the Japanese building group. This study found a conflict comparing the perceptional differences between the types of cognition. This study is meaningful in that it provides an in-depth approach to the perspectives of the stakeholders concerned with the Japanese-style buildings clustered in central Seoul. It is also meant to present a theoretical framework that can be applied to the use area as sustainable cultural heritage through the establishment of preservation and utilization of Japanese-style areas and conflict resolution.
\end{abstract}

Key Words: Recognition Survey, Heritage Value, Japanese Colonial Period, Qualitative Research Methods, Subjectivity Research

Corresponding author: Jong-sang Sung, Professor, Graduate School of Environmental Studies, Seoul National University, Seoul 08826, Korea, Tel.:+82-2-880-1423, E-mail: jssung@snu.ac.kr 


\section{국문초록}

후암동은 일제강점기의 대표적인 일본인 거주지로 서울 내에 가장 많은 일본식 건물이 남아있는 공간이다. 2001년 등록문화재, 2015년 건축자산, 2018년 문화재청의 선·면 단위 문화재 등록제도가 지정되는 등 근대문화유산에 관한 관심은 높아지고 있다. 또한, 일제강점기 수탈의 기억을 떠올리게 하는 근대문화유산 보존의 필요성에 대한 논쟁이 심화되면서, 가치평가와 함께 이해관계자의 인식을 파악하는 연구가 요구되고 있다. 본 연구는 후암동 일본식 건물군에 관한 이해관계자(소유자, 임대자, 방문자)의 주관적 인 식유형을 확인하고, 유형별 특징을 분석, 논점을 도출하였다. 연구방법으로는 인간의 주관적 인식을 조사하여 유형화할 수 있는 통 계적 기법인 Q 방법론을 활용하였다. 후암동과 근대문화유산 가치에 관한 문헌연구를 진행, 5 가지 측면의 근대문화유산 가치(역사 적, 건축적, 사회문화적, 경관적, 경제적 가치)를 바탕으로 $\mathrm{Q}$ 설문을 진행하였다. 연구결과, 일본식 건물군에 대한 3 가지의 인식유 형(유형1:사회문화 - 역사적 가치 결합형, 유형2:경제적 가치 중시형, 유형3:사회문화 - 경제적 가치 결합형)이 도출되었다. 이후 본 연구는 유형 간 인식 차이를 비교하여 가치충돌 지점을 발견하였다.

본 연구는 서울 중심부에 밀집된 일본식 건물군에 대하여 이해관계자들이 가지고 있는 관점에 대해 심층적으로 접근하였다는 점에서 의미가 있다. 또한, 향후 일본식 건물 밀집 지역에 대한 보존 및 활용의 기초자료 구축과 갈등 해결을 통한 지속 가능한 면 적 문화유산 활용에 적용할 수 있는 이론적 틀을 제시하였다는 의의가 있다.

\section{주제어: 인식조사, 유산가치, 일제강점기, 질적연구방법론, 주관성 연구}

\section{I. 서론}

\section{1. 연구 배경 및 목적}

2001년 7월 「문화재보호법」개정으로 등록문화재에 대한 제 도가 시행되었고, 2015년 건축자산 제도가 시행되는 등 근대문 화유산의 보존에 관한 관심이 높아지고 있다. 특히 근대건축물 은 현재에도 충분한 활용이 가능하다는 점에서 도시재생과 지 역 경관 창출의 도구로 사용되곤 한다. 2018년 8월 문화재청은 선·면 단위 문화재 등록제도를 도입하여 군산, 목포, 영주를 최초의 근대역사 문화공간으로 등록 고시하였다. 이는 근대문화 유산의 다각적 보존과 활용뿐만 아니라, 근대건축물의 밀집으로 형성되는 근대역사 경관을 제도화했다는 점에서 의미가 있다.

다수의 학자는 대한민국의 근대를 고종원년인 1863년부터 1960년대까지 약 100년 동안으로 보고 있다(Kim, 2017). 1910 년부터 1945년까지 총 35년간 일제강점의 식민통치가 이루어 졌고, 일제강점기 이전에도 1904년 러일전쟁, 1894년 청일전쟁 으로 인하여 한반도는 일본 제국주의 영향권이었다. 다시 말해 우리나라 다수의 근대문화유산은 식민지 역사와 깊은 관련이 있다. 이 때문에 근대문화유산을 바라보는 시각은 크게 대립하 곤 한다. 불과 얼마 전까지 적의 재산이라는 뜻의 적산가옥이 라 불리며 치욕적인 역사의 흔적으로 여겨지면서 일본식 건물 군은 도시개발 과정에서 많이 소실되었다. 반면, 최근에는 네거 티브 헤리티지(negative heritage)의 관점과 귀속재산에 대한 불하(拂下)로 일제강점기에 건설되었을 뿐, 긴 시간 우리 삶의 터전이었다는 점에서 보존해야 한다는 움직임이 일고 있다.
이러한 논쟁에도 불구하고 일본식 건물 밀집 지역에 관한 연 구는 미비하다. 대개의 연구는 일제 재산의 귀속 과정, 단일 건 축물에 대한 문화재 가치, 주택발전사에서 일본식 주택의 의미 등에 한정되었다. 그러나 근대문화유산은 지역주민의 삶 속에 서 형성된 문화경관이므로 개별 건축물에 대한 가치평가뿐만 아니라, 이를 둘러싼 환경과 시스템의 이해, 사회문화적 가치 등을 반영해야 한다(Park and Sung, 2013). 건축물은 지역의 경관을 형성하는 대표적인 요소로서 지역의 고유한 경관을 유 지하기 위해서는 이론적 논의뿐만 아니라, 지역사회의 인식을 들여다볼 필요가 있다.

본 연구는 근대문화유산 가치를 바탕으로 용산구 후암동 일 본식 건물 밀집 지역에 대한 이해관계자의 주관적 인식 유형화 에 목적이 있다. 후암동을 대상지로 선정한 이유는 역사적으로 중요한 근대문화유산이 기념물로서 존재하는 것이 아니라, 일 상공간 속에 근대문화유산이 함께 하고 있어 이해관계자들의 인식을 파악하는 과정이 더욱 중요하기 때문이다. 연구방법은 인간의 자작적 주관성을 측정하고, 이를 토대로 인간의 공통 적 관점을 추출하는 통계적 기법(Kim, 2016b)인 Q 방법론을 사용하여 후암동 일본식 건물군에 관한 깊은 이해와 함께 논 점 도출을 목표로 한다. 연구대상자는 건물에 직접적 권리를 행사할 수 있는 후암동 주민(소유자, 임대자)과 현재 후암동 공간을 소비하고 있는 방문자(관광객)를 대상으로 한다. I, II 장은 연구의 공간적 범위인 후암동과 근대문화유산 가치에 관 한 문헌연구, III, IV장은 후암동 일본식 건물군의 이해관계자 를 대상으로 한 $\mathrm{Q}$ 연구 설계와 결과, $\mathrm{V}$ 장 결론의 순서로 연 구는 진행된다. 


\section{2. 연구 대상지}

연구 대상지는 러일전쟁 이후 일본군 병영 건설로 ${ }^{1)}$ 대표적 인 일본인 거주지였던 서울시 용산구 후암동 일대이다. 후암동 은 1914년에 삼판동(三坂洞)으로 개명되었고, 1946년 본래의 이름인 '후암로 다시 명명되었다. 일제강점기 삼판동은 현재의 후암동과 갈월동이 합쳐진 범위로 일본인 상류층 거주지가 분 포하였다. 일본식과 구라파식이 섞인 일명 ‘문화주택' 밀집 지 역으로 유명하였다(Seoul Museum of History, 2016). 후암동의 대표적 근대경관은 일본식 건물 중에서도 문화주택의 군집이 다(Figure 1 참조)

후암동은 북쪽과 동쪽으로 남산에 둘러싸여 있고, 서쪽으로 는 용산역과 서울역, 남쪽으로는 용산미군기지가 위치한다 (Figure 2 참조). 지리적으로 서울의 중심이나 섬처럼 고립된 공간인 후암동은 서울에서도 과거 경관이 비교적 잘 보존되었 다. 2019년 3월 4일 등록된 국토교통부 건물통합정보를 기준으 로 후암동 내 일제강점기에 등록된 건물은 105 개가 존재한다. 후암동의 전체 건물 수(2,317개)와 비교해 보면 $4.53 \%$ 로 서울 평균 $(0.53 \%)$ 보다 크게 높은 수치이다. 그러나 건물통합정보는 건축물대장이 존재하는 건축물 정보만을 대상으로 한다. 또한, 옛 건물일수록 건축물대장에 등록일 정보의 누락이 많다는 점 에서 실제로 후암동에는 더 많은 일본식 건물이 존재한다고 판 단된다. 이렇듯 후암동은 대도시 서울의 중심에서 70 년 이상의 근대 건물이 밀집된 장소이다. 불과 2년 전까지만 하더라도 용 산 일대의 일본식 건물들은 철거 후 다세대 건물로 신축하는 것이 일반적이었다. 그러나 이제 젊은 세대는 생경한 풍경에
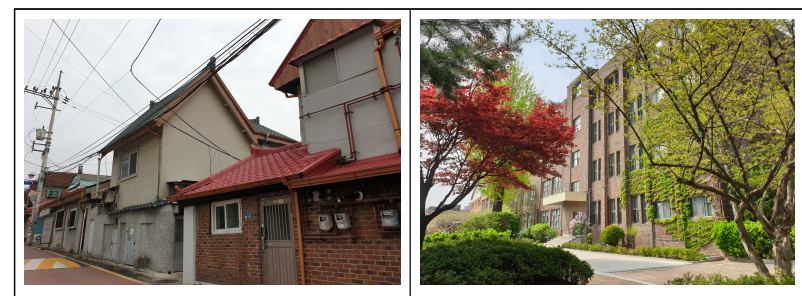

a: Duteobbawi-ro 1 na-gil (Across from b: The Japanese style elevation Sam-Gwang Elementary School of Sam-Gwang Elementary School

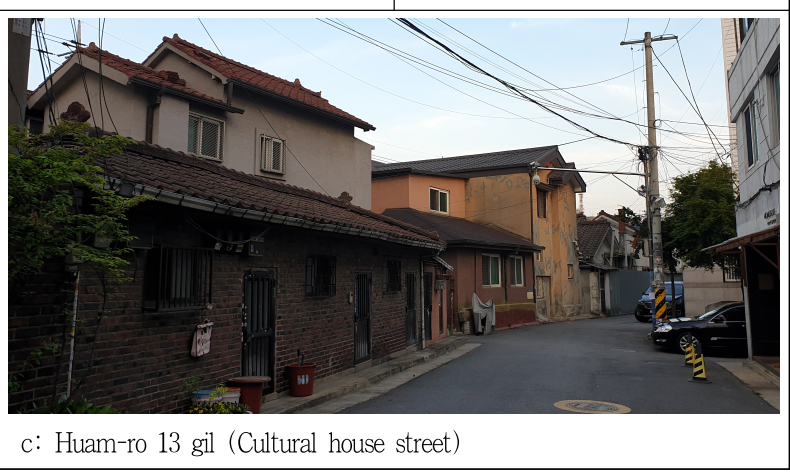

Figure 1. Modern landscape of Huam-dong

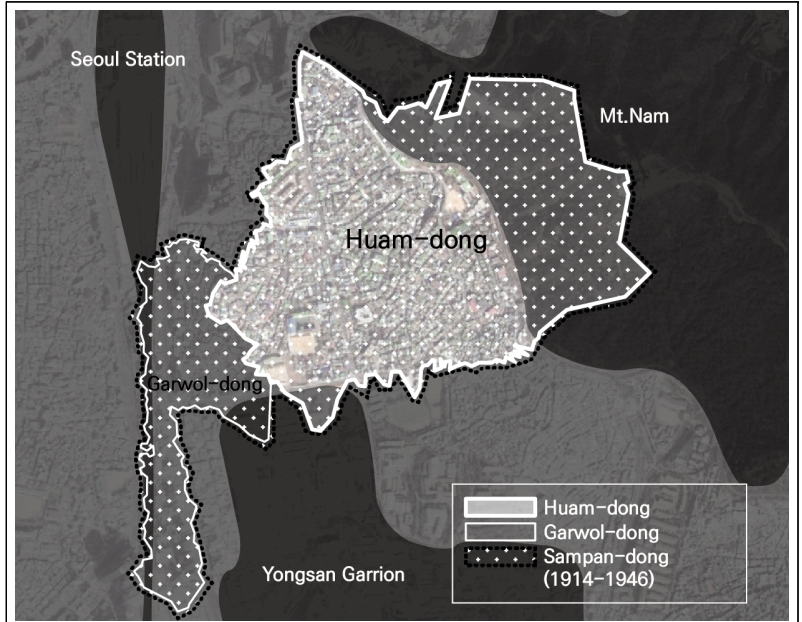

a: The location of Huam-dong

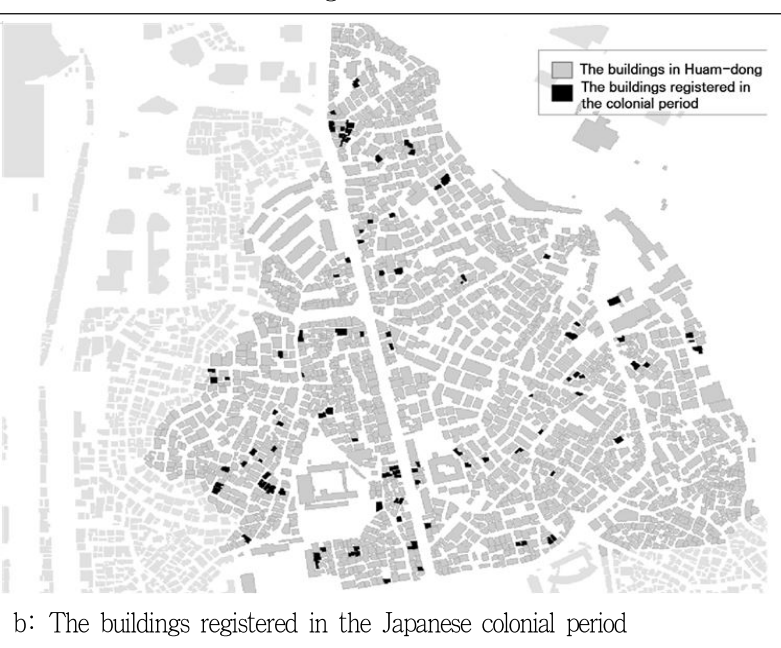

Figure 2. The location of Huam-dong and the buildings registered in the Japanese colonial period

매료되어 이곳을 찾고 있고, 일본식 건물은 카페, 식당, 게스트 하우스 등 상업시설로 활용하는 사례가 늘고 있다(Table 1 참 조). 다른 일본식 건물 밀집 지역과 마찬가지로 후암동의 일본 식 건물군을 바라보는 시선이 곱기만 한 것은 아니다. 적산가 옥을 찾아가는 젊은이들과 그것을 경제적 수단으로 활용하는 상업종사자를 이해하지 못하거나 혹여 후암동이 면적 근대문 화유산으로 인정받아 재산권 행사에 문제가 생기는 상황을 걱 정하는 의견도 있다 ${ }^{2)}$. 이처럼 보전과 소실의 경계에 있는 후암 동을 대상지로 선정하여 본 연구를 진행하였다.

\section{3. 연구의 방법: 0 방법론}

본 연구는 일본식 건물이 밀집된 후암동에 대한 주민 - 방문 자 인식을 유형화하기 위하여 Q 방법론을 사용하였다. Q 방법 론은 요인분석(factor analysis)의 하나로 특정 주제나 현상에 대해 개인이 가지고 있는 각기 다른 느낌, 가치, 믿음, 신념, 관 
Table 1. The cases on the use of Japanese-style building in Huam-dong area

\begin{tabular}{|c|c|c|c|c|c|}
\hline Address & 250-5, Huam-dong & 439-3, Huam-dong & 52-4, Galwol-dong & 236-1, Huam-dong & 194-10, Huam-dong \\
\hline Name & Jiwoljang & Nook Seoul & Anarchy Bros & Cupboard & Dosigonggam Office \\
\hline \multicolumn{6}{|l|}{ Photo } \\
\hline Now Use & Accommodations & Accommodations & Cafe \& Pub & Restaurant & Office \\
\hline Past Use & House & House & House & $\begin{array}{c}\text { House (Railroad } \\
\text { employee's lodging) }\end{array}$ & House \\
\hline Feature & $\begin{array}{l}\text { - Preservation of house \& } \\
\text { garden } \\
\text { - Filming location 'Wani } \\
\text { and Junha' }\end{array}$ & $\begin{array}{l}\text { - Exterior material } \\
\text { changed } \\
\text { - Inside:good preservation } \\
\text { of wood }\end{array}$ & $\begin{array}{l}\text { - Use buildings as a } \\
\text { means of promotion } \\
\text { - Good preservation }\end{array}$ & $\begin{array}{l}\text { - Take advantage of } \\
\text { exoticism with French } \\
\text { food } \\
\text { - Facade brick }\end{array}$ & $\begin{array}{l}\text { - Preservation of the } \\
\text { facade } \\
\text { - Operation of project to } \\
\text { record Huam Houses }\end{array}$ \\
\hline
\end{tabular}

점 등과 같은 주관적인 반응을 유형별로 묶어 분석한다(Park et al., 2010). 전통적인 요인분석인 R-type의 요인이 변수라면, Q-type은 사람을 요인으로 집약·분석하는 방법으로 그 차이 는 Table 2와 같다. 따라서 양적 연구가 어려운 인식과 갈등 구 조 등을 객관적으로 ${ }^{3)}$ 분석하기에 유용한 연구방법이다. $\mathrm{Q}$ 방 법론은 모든 사회현상이 본질적으로 주관적이라는 가정에 기 반을 둔다. 연구자는 특정 주제에 대한 주관성을 나타내는 $\mathrm{Q}$ 진술문을 작성하고, 연구대상자는 본인의 선호에 따라 $\mathrm{Q}$ 진술 문을 배열한다. 연구자가 연구대상자의 행태나 태도를 제약하 는 정량적 연구방법과 달리 $\mathrm{Q}$ 방법론은 연구대상자가 자율적 으로 결정하기 때문에 연구자의 조작에 좌우되지 않는 장점을 갖고 있다(Whang and Choe, 2002).

$\mathrm{Q}$ 방법론은 가설발견의 논리(Abductive Reasoning)의 특징 을 갖고 있다(Kim, 2010a; 2016b). 가설발견의 논리는 귀납적 논리와 연역적 논리 등이 구체적으로 적용되기 이전 단계에 연 구대상에 대한 추측(hunch) 단계를 말한다(Kim, 2010a). 비슷 한 생각이나 느낌이 드는 요인을 추출하는 $\mathrm{Q}$ 방법론은 연구 결
과를 일반화할 수는 없다. 그러나 요인의 특성, 연구대상의 배 경적 변수 등에 관한 흥미로운 결과가 발견되고, 후속 연구를 촉진 - 배가시킬 수 있다. 이는 Q 방법론을 탐색적 연구이자 후 속 연구의 길잡이 기능이 있다고 평가하는 이유이다.

Q 방법론의 시작은 1935년 네이처지의 "Technique of Factor Analysis"라는 제목의 스테펜슨(William Stephenson)의 논문 이다. 당시 스테펜슨은 나이, 성별, 신장, 키, 체중, 지능 등과 같은 인간의 배경 변수 간의 요인분석으로 인간의 성격이나 인 식 형태를 정확히 설명할 수 없다고 주장하였다. 이후 그는 인 간의 배경적 변수가 아닌 사람 간의 상관관계를 기초로 하는 요인분석의 필요성과 주관성과 객관성 사이의 긴장 해소의 방 법으로 $\mathrm{Q}$ 방법론을 제시하였다. 스테펜슨은 언론학으로 관심분 야를 옮겼고, 자연스럽게 언론학에서의 $\mathrm{Q}$ 방법론은 발전되었다. 또한 $\mathrm{Q}$ 방법론은 주관성이 중요한 학문인 심리학, 정치 및 행정 학, 간호학 등에서 널리 사용되고 있다(Kim, 2010a; 2016b).

조경, 경관, 건축, 지리학 등의 장소를 기반으로 하는 학문 분야에서는 장소에 대한 여러 집단의 주관적 인식과 갈등을 연

Table 2 . Difference between R-type and Q-type, a kind of factor analysis

\begin{tabular}{|c|c|c|}
\hline & R-type & Q-type \\
\hline Study subject & Data based on the objective measurement of the researcher & Subjective data such as the state of mind \\
\hline Objectivity & $\begin{array}{l}\text { Application of objective measurement tools } \\
\text { Complete exclusion of individual subjectivity }\end{array}$ & $\begin{array}{l}\text { Naturally expressing one's perception of a particular subject accor- } \\
\text { ding to the research participant(subject)'s frame }\end{array}$ \\
\hline Data collecting & $\begin{array}{l}\text { According to the researcher's point of view, assumed variables are } \\
\text { represented as measurable indices. } \\
\text { The operational definition and scale of the variables are determined } \\
\text { by the researcher. }\end{array}$ & $\begin{array}{l}\text { The researcher does not determine operational definitions and } \\
\text { measures for the variables. } \\
\text { The research participants (subjects) voluntarily express their opinions } \\
\text { on the research topic. }\end{array}$ \\
\hline Analysis method & $\begin{array}{l}\text { Factor analysis based on comparisons between individual variables or } \\
\text { relationships between several variables }\end{array}$ & Factor analysis based on correlation between humans \\
\hline Study purpose & Discover the structural features of the study subject & $\begin{array}{l}\text { Identify the structure of subjective opinions or perceptions of subjects } \\
\text { on a particular subject }\end{array}$ \\
\hline
\end{tabular}

* Source: Hong (2019) 
구하는 것이 꾸준히 이루어져 왔다. 그러나 그 방법론은 심층 인터뷰에 한정되었다. 연구자에 의한 연구의 오염이 가능한 심 층 인터뷰와 비교하면 $\mathrm{Q}$ 방법론은 주관성을 객관적인 방법으 로 이해하고자 하는 방법론이다. 공간에 대한 인식, 갈등 양상, 공간 기초 연구 등 조경학 전반에서 활용할 수 있다.

\section{II. 근대문화유산 가치 기준에 대한 논의}

\section{1. 선행연구 검토}

근대문화유산은 보전가치가 있으나, 현실의 여러 제약으로 인해 쉽게 보전될 수 없는 것이며, 이러한 '가치의 상충성'이 근 대문화유산의 본질이다(Cho, 2001). 단순히 제작 시기가 근대 라는 이유로 의미 있는 것이 아니라, 유산가치(Heritage Value) 를 가진 것을 근대문화유산이라 하며, 보존하고 활용할 필요가 있다. 본 연구는 근대문화유산 가치가 후암동의 일본식 건물군에 대한 가치 판단 기준이 될 수 있다는 것을 전제로 한다.

문화유산 가치에 관한 연구는 정량적으로 측정할 수 있는 경 제적 가치에 대한 연구(Lee and Kim, 2011; Ok and Park, 2011; Song and Kim, 2012; Kim, 2017)에 집중되었다. 이를 두고 Randall Mason(2002)은 유산의 성격과 시간에 따른 가치 변화, 경제적 기회와 문화적 추세와 같이 보이지 않는 흐름에 의해 유산가치를 평가하는 데는 방법론적 어려움이 발생하기 때문이라고 설명한다. 그 때문인지 선행 연구자들은 다른 유산 가치의 연구(Lee, 2011; Oh and Cho, 2017; Song and Kim, 2018)에서도 정량적 방법론을 선택하였다. 이러한 근대문화유 산 가치 '평가' 연구는 해당 문화유산을 둘러싼 사람들의 생각 을 충분히 담지 못하며, 다수 의견만이 강조된다. 그러나 근대 문화유산의 경우, 대부분 특정인의 소유이자 이해관계가 복잡 하므로 사람들의 인식은 더욱 중요하다.

정성적 방법을 활용한 근대문화유산 가치 연구로는 근대문 화유산 담론을 통해 도시 정체성의 변화를 본 $\mathrm{Hong}(2008 \mathrm{a})$ 과 구 조선총독부 철거 논쟁을 바라본 Son and Pae(2018) 등이 있다. 정성적 연구방법을 사용한 연구들은 대개 근대문화유산 의 가치 변화와 충돌을 고찰하지만, 근대문화유산의 가치 인식 을 알아보거나 유형화하지 않는다. 그러나 근대문화유산에 대 한 가치 변화와 충돌은 실제 그곳을 소유하거나 사용하는 사람 들의 인식이 중요하다는 점에서 문헌연구에 한정된 선행연구 를 보완할 수 있는 이해관계자의 인식 연구가 필요하다.

그 이외의 선행연구는 대부분 근대문화유산 목록화와 역사 성 고찰(Yang, 2012; Choi and Lee, 2013; Kim, 2016a; Ryu, 2016a; Je and Song, 2017) 또는 근대문화유산의 보존과 활용 계획에 관한 연구(Kim, 2010b; Cho, 2016b; Dan and Choi, 2017; Lee and Park, 2018)이다. 한편, Park and Shin(2014)은
$\mathrm{Q}$ 방법론을 활용하여 근대건축물 보존과 활용에 관한 전문가 의식을 유형화하였다. 그러나 근대문화유산에 대한 실제 권리 를 가진 이해관계자 의견이 반영되지 않았다.

\section{2. 근대문화유산 가치의 분류}

대한민국에서 근대문화유산 가치 기준에 관한 연구는 2001 년 등록문화재 제도 시행 전인 1990년대 후반부터 꾸준히 진행 되었다. 근대문화유산 중 건축물에 관한 가치는 연구가 발전됨 에 따라서 다양하게 제시되었는데, 기존에 모호한 가치를 구체 화하였고 사회적 변화에 따라 가치 판단의 기준이 변화했기 때 문이다(Table 3 참조). 실례로 Lee(1996)와 Jeon(1999)의 역 사적 가치는 이후 연구자들이 건축적 가치로 표현한 건축적 구 조, 양식, 재료를 포함한다. 경관적 가치는 2005년부터 지속해 서 등장한다는 점에서 시대에 따라 가치가 변화한 사례이다. 본 연구는 선행 연구의 가치 내용을 종합, 비교 - 분석하여 근 대문화유산의 가치를 5 가지로 나누었고 그 내용은 다음과 같다.

\section{1) 역사적(Historical) 가치}

역사적 가치에는 오래된 정도, 역사적 사건, 인물과의 연관 성 등이 해당한다. 연구자 대부분은 '역사적 가치'로 표현하였 으나, Park(2003)은 '역사 · 문화적 가치'로 표현하고 역사의 층 4)을 강조하였다. 한편, $\mathrm{Cho}$ (2012)는 건축물의 과거 기능이 건 축물의 역사를 나타내거나, 기능 자체가 역사적 의미를 지닌 '기능적 가치'를 제시하였다. 군사배후지로 일본인의 거주지였 던 과거 후암동 주택의 기능은 이에 해당하므로 본 연구에서는 과거의 기능을 역사적 가치에 포함한다. Cho(2016a)는 학문적 인 연구의 필요성을 가진 건축물과 시간의 흐름을 지닌 고고학 적 특성을 보인 건축물을 예로 들면서 '학술적 가치’를 설명하 였다. 본 연구에서는 건축학에 해당하는 전자의 경우는 건축적 가치에, 시간성을 의미하는 후자의 경우는 역사적 가치로 구분 한다.

\section{2) 건축적(Architectural) 가치}

건축적 가치는 건축적 구조, 양식, 재료 등으로 구분되며, 한 시대의 전형적 구조이거나 혹은 희소성과 독특성, 심미성 등을 포함한다. 따라서, 건축적 가치는 학술 가치를 포함하며, 시대 를 떠나 저명한 건축가의 작품과 그의 건축적 특징을 보여주는 건물도 건축적 가치가 뛰어나다고 할 수 있다. Lee(1996)와 Jeon(1999)은 건축적 가치를 역사적 가치에 포함하였으나, 본 연구의 건축적 가치는 역사적 가치와 달리 가시적으로 드러나 는 가치를 의미한다. 따라서 건축물의 외형, 양식, 디테일이 보 여주는 아름다움을 의미하는 Hong(2008b)의 심미적 가치는 본 연구에서 건축적 가치와 같다. 
3) 사회문화적(Sociocultural) 가치

사회문화적 가치는 지역의 문화와 지역성을 드러내는 정도 를 의미한다. 다시 말해 건축물이 지역을 상징하는 정도라 할 수 있으므로 지역 랜드마크를 의미하는 Jung(2005)과 Cho(2012) 의 상징적 가치는 본 연구의 사회문화적 가치에 해당한다. 사 회문화적 가치는 눈에 보이지 않는 무형의 가치라 생각할 수 있으나, 지역사회 커뮤니티를 발현시키는 사회자산이 되고, 이 는 문화예술 창작물로 가시화되기도 한다. 이에 건축 자체가 1 급이 아니더라도 지역성이나 사회성을 가지고 지역문화 진흥 에 도움이 되는 건축물로 설명한 $\mathrm{Cho}$ (2012)의 '문화재적 가치' 도 본 연구의 사회문화적 가치에 해당한다.

\section{4) 경관적(Landscape) 가치}

2000년대부터 유산가치에 등장하기 시작한 경관적 가치는 주 변 경관과의 관계에서 발견되는 가치를 말한다. 점(點) 적 문화 유산 관점에서 변화를 보여주는 가치 유형이며, 용어 정립이 되지 않은 탓에 연구자들은 지역(Local), 맥락적(Contextual), 도시 맥락적(Urban-Contextual) 등 다양하게 표현하고 있다. 본 연구에서는 환경과 분위기를 포함한다는 점에서 경관적 가 치로 명명한다. 경관적 가치는 (1)특정 건조물이 주변 경관과 형성하는 조화로움, (2)특정 범위 안에 모여있는 건조물들이 형 성하는 독특한 경관으로 구분된다. 전자의 경우, 단일 문화유산 의 중심으로 경관을 바라본 것으로 근대문화유산 가치 기준을 제시한 앞선 선행연구의 모든 경관적 가치는 이에 해당한다. 반면, 후자의 경관적 가치는 최근 시행된 선 - 면 단위 등록문 화재와 우수건축자산 제도에서 찾아볼 수 있다.

\section{5) 경제적(Economic) 가치}

경제적 가치는 구조나 설비 등이 튼튼하여 유지하는데 비용 이 들지 않거나 건물을 활용하여 수익상승이 기대되는 등의 문 화유산의 실용성에 집중한다. 과거와 달리 문화유산의 가치는 보존가치에서 경제적 이익을 얻을 수 있는 활용 가치를 강조하 는 경향을 보인다(Randall, 2002). 특히 비교적 짧은 역사를 가 진 근대문화유산의 경우 경제적 가치는 더욱 중요한 위치에 있 다. 때문에, 근대문화유산의 가치 기준에 관한 대부분의 연구에 서 경제적 혹은 실용적 가치라는 이름으로 등장한다. 경제적 가치에는 해당 건조물의 수익과 성능 등 현재 시점에서의 경제 성과 기능적 잠재력과 같은 미래 시점의 경제성을 모두 포함한 다. 특히 관광 목적지로서의 가능성은 대표적인 경제적 가치에 해당하는 사례이다. 이를 바탕으로 볼 때, $\operatorname{Park}(2003)$ 의 '지속 가능한 보존의 가치'와 $\mathrm{Cho}$ (2012)의 '창조적 가치'는 해당 공간 의 활용 가치에 집중한 것으로 경제적 가치에 포함된다.

\section{III. 연구 설계}

\section{Q 진술문 구성}

$\mathrm{Q}$ 진술문은 연구대상자의 주관성이 나타나는 범위가 되기 때문에 Q 방법론 사용에 있어 매우 중요하다. 진술문은 연구대 상에서 나타날 수 있는 관점들을 포괄하여 집합적으로 구성해 야 하고, 사실이 아닌 개인의 생각이 드러날 수 있도록 가치가 부여된 문장이어야 한다(Kim, 2016b).

본 연구에서는 사용된 30 개의 진술문은 다음의 과정을 거쳐 선정되었다. 첫째, 후암동에 관한 선행연구, 신문기사와 더불어 근대문화유산에 관한 기사 등에서 72 개의 문장을 추출하였다. 둘째, 문장은 Table 3 을 바탕으로 구성한 근대문화유산의 5 가 지 가치 기준으로 재분류하였다. 이 과정에서 $5 \times 2^{5)}$ 의 피셔식

Table 3. The heritage value of modern cultural heritage

\begin{tabular}{|c|c|c|c|c|c|c|c|c|c|c|}
\hline \multirow{2}{*}{ Researcher } & \multicolumn{10}{|c|}{ Heritage value } \\
\hline & Num. & \multicolumn{2}{|c|}{ Historical } & \multicolumn{2}{|c|}{ Architectural } & \multicolumn{2}{|c|}{ Sociocultural } & Landscape & \multicolumn{2}{|c|}{ Economic } \\
\hline Lee(1996) & 3 & \multicolumn{2}{|c|}{ Historical } & \multicolumn{2}{|c|}{ Historical } & \multicolumn{2}{|c|}{ Social } & & \multicolumn{2}{|c|}{ Economic } \\
\hline Jeon (1999) & 4 & \multicolumn{2}{|c|}{ Historical \& architectural } & \multicolumn{2}{|c|}{ Historical \& architectural } & \multicolumn{2}{|c|}{ Social } & Environmental & \multicolumn{2}{|c|}{ Practical } \\
\hline Lee $(2000)$ & 4 & \multicolumn{2}{|c|}{ Historical } & \multicolumn{2}{|c|}{ Architectural } & \multicolumn{2}{|c|}{ Cultural } & & \multicolumn{2}{|c|}{ Practical } \\
\hline Lee(2003) & 4 & \multicolumn{2}{|c|}{ Historical } & \multicolumn{2}{|c|}{ Architectural } & \multicolumn{2}{|c|}{ Cultural } & & \multicolumn{2}{|c|}{ Practical } \\
\hline $\operatorname{Park}(2003)$ & 3 & \multicolumn{2}{|c|}{ Historical \& cultural } & \multicolumn{2}{|c|}{ Sustainable conservation } & & & & $\begin{array}{l}\text { Socio- } \\
\text { economic }\end{array}$ & $\begin{array}{l}\text { Sustainable } \\
\text { conservation }\end{array}$ \\
\hline Jung(2005) & 7 & \multicolumn{2}{|c|}{ Historical } & Architectural & Academic & \multicolumn{2}{|c|}{ Symbolic } & Local & Practical & Economic \\
\hline Hong(2008b) & 4 & \multicolumn{2}{|c|}{ Historical } & \multicolumn{2}{|c|}{ Aesthetic } & \multicolumn{2}{|c|}{ Social } & Contextual & & \\
\hline Cho(2012) & 7 & Historical & Functional & \multicolumn{2}{|c|}{ Architectural } & $\begin{array}{l}\text { Cultural } \\
\text { heritage }\end{array}$ & Symbolic & & Economic & Creative \\
\hline $\begin{array}{c}\text { Kim and Kim } \\
(2012)\end{array}$ & 5 & \multicolumn{2}{|c|}{ Historical } & \multicolumn{2}{|c|}{ Architectural } & \multicolumn{2}{|c|}{ Social } & Urban-contextual & \multicolumn{2}{|c|}{ Economic } \\
\hline Cho(2016a) & 6 & Historical & Academic & Architectural & Academic & \multicolumn{2}{|c|}{ Socio-cultural } & Contextual & \multicolumn{2}{|c|}{ Practical } \\
\hline
\end{tabular}


실험 및 분산분석 설계의 원리를 바탕으로 작성되었기에 본 연 구의 Q 진술문은 구조적 진술문에 해당한다(Table 4 참조). 셋 째, 유사한 의견을 삭제 - 재조합하였다. 마지막으로 찬성과 반 대가 균형 있게 배치되도록 $\mathrm{Q}$ 진술문을 재구성하였다. 본 진술 문은 조경학 전문가 1 인, 질적연구방법론 전문가 1 인이 교차 검토하여 내용 타당성을 확인하였다.

\section{2. 연구대상자 선정 및 $\mathrm{Q}$ 설문}

본 연구의 대상자(P표본)는 후암동 근대문화유산의 실제 이 해관계자인 거주민과 장소 소비자인 방문자이다. Q 방법론은
인간의 주관성을 연구하므로 $\mathrm{P}$ 표본의 선정이나 표본 수에 대 한 제한이 없다 $(\mathrm{Kim}, 2016 \mathrm{~b})^{6)}$. 그러나 본 연구에서는 후암동 일본식 건물군에 대한 주관적 인식에 영향을 줄 수 있다고 생 각되는 거주지, 거주 유형, 성별, 나이를 균형 있게 반영하고자 노력하였다. 연구대상자인 이해관계자와 장소 소비자는 별도로 모집하였다. 이해관계자 모집을 위하여 연구자는 후암동 적산 가옥 밀집 지역에 있는 건물 우편함에 100 장의 연구대상자 모 집문을 2019년 5월 1일 배포하였고, 후암동 거주자 13명이 연 구 참여하였다. 장소 소비자는 후암동의 주요 관광지로 활용되 고 있는 식음료점 2곳에 2019년 5월 3일 5일, 10일 12일 방 문객 중 후암동과 연고가 없는 주말 나들이객 8 명을 대상으로

Table 4. Q Sentences

\begin{tabular}{|c|c|c|}
\hline & & Q Sentence \\
\hline \multirow{6}{*}{$\begin{array}{c}\text { Historical } \\
\text { value }\end{array}$} & Q1 & Huam-dong buildings are living data of housing change in Korea. \\
\hline & Q2 & Huam-dong buildings are not old enough to be a Heritage. \\
\hline & Q3 & Through Huam-dong, you can know the buildings, roads, and village types from 1920 to 1940. \\
\hline & Q4 & There are no historical events or characters related to Huam-dong. \\
\hline & Q5 & When you go to Huam-dong, it seems to take time travel into modern history decades ago. \\
\hline & Q6 & $\begin{array}{l}\text { The buildings of Huam-dong that were built during the Japanese colonial period can not be seen as traces of our country's } \\
\text { history. }\end{array}$ \\
\hline \multirow{6}{*}{$\begin{array}{l}\text { Architectural } \\
\text { value }\end{array}$} & Q7 & The shape of the Huam-dong building is beautiful, such as a sharp roof, a long eave, and protruding windows. \\
\hline & Q8 & Huam-dong Japanese-style buildings are common in other places. \\
\hline & Q9 & $\begin{array}{l}\text { Huam-dong is unique because it can be seen building materials that are not used well these days such as wooden roof, brick or } \\
\text { tile outer wall. }\end{array}$ \\
\hline & Q10 & Huam-dong buildings are not well preserved because of the many remodeling and the architectural aspects are not very good. \\
\hline & Q11 & Huam-dong buildings are a unique architectural style mixed with Japanese traditional style and western modern style. \\
\hline & Q12 & The buildings of Huam-dong, not the works of famous architects, are of low value to preserve. \\
\hline \multirow{7}{*}{$\begin{array}{l}\text { Sociocultural } \\
\text { value }\end{array}$} & Q13 & Utilizing the Japanese-style buildings plays a big role in forming the local culture of Huam-dong. \\
\hline & Q14 & Preserving or utilizing Japanese buildings in Huam-dong can make a false sense of history. \\
\hline & Q15 & The buildings of Huam-dong can be the background of literature and art. \\
\hline & Q16 & Japanese-style buildings deteriorate the pride of residents in Huam-dong. \\
\hline & Q17 & Japanese-style buildings help to understand Huam-dong. \\
\hline & Q18 & Huam-dong Japanese-style building group has low recognition to outsiders. \\
\hline & Q19 & Huam-dong is like a movie set where people do not live. \\
\hline \multirow{5}{*}{$\begin{array}{l}\text { Landscape } \\
\text { value }\end{array}$} & Q20 & Huam-dong buildings fit well with the surrounding environment that leads to Mt.Nam. \\
\hline & Q21 & Old buildings in Huam-dong give a dirty impression. \\
\hline & Q22 & The streetscape of Huam-dong is exotic. \\
\hline & Q23 & It is not interesting to see Huam-dong, where similar buildings are gathered. \\
\hline & Q24 & The roofline (skyline) of Huam-dong, made by pointed roofs, is valuable. \\
\hline \multirow{6}{*}{$\begin{array}{l}\text { Economic } \\
\text { value }\end{array}$} & Q25 & The Huam-dong buildings are a popular tourist resource for the younger generation. \\
\hline & Q26 & It is better to break old buildings and build new ones. \\
\hline & Q27 & The Huam-dong Japanese-style building is highly utilized, so I would like to purchase it if possible. \\
\hline & Q28 & $\begin{array}{l}\text { When the Huam-dong area is designated as a modern cultural heritage (area), redevelopment problems arise. (property rights, } \\
\text { building renovation, etc.) }\end{array}$ \\
\hline & Q29 & The commercial space where Japanese-style buildings are recycled has a high sales. \\
\hline & Q30 & As it is an old building, it costs a lot of maintenance. \\
\hline
\end{tabular}


하였다. 최종적으로 연구 참여자는 건물 소유자 7 명, 건물 임대 자 6명, 방문객 8명으로, 세 계층의 비율을 맞추고자 하였다 (Table 5 참조).

조사 기간은 2019년 5월 3일부터 6월 2일까지이다. 조사는 $1: 1$ 면접을 원칙으로 하였고, 설문 시 응답자의 기본사항(성별, 나이, 거주지, 거주기간)을 수집하였다. 설문 방법은 응답자에 게 $\mathrm{Q}$ 진술문 30 개를 카드 형태로 제공하고, 본인의 동의 정도 에 따라 강제 배분하도록 하였다(Figure 3 참조). 이때, 매우 동의하는 경우 +4 , 매우 동의하지 않는 경우는 -4 에 해당하 며, Figure 4 는 Q 표본의 분포이다. 강제 배분이 완료된 후 연 구자는 연구대상자에게 $\mathrm{Q}$ 표본의 양극단에 배치한 이유에 대 해 추가 질문하였닥)

Table 5. P Sample

\begin{tabular}{|c|c|c|c|c|}
\hline & Category & Residence period(year) & Gender & Age \\
\hline P1 & Owner $^{b}$ & 50 & Male & 80 \\
\hline P2 & Owner $^{a}$ & 20 & Female & 50 \\
\hline P3 & Owner $^{c}$ & 20 & Male & 30 \\
\hline P4 & Owner $^{b}$ & 10 & Male & 60 \\
\hline P5 & Owner $^{\mathrm{a}}$ & 5 & Female & 40 \\
\hline P6 & Owner & 3 & Male & 30 \\
\hline P7 & Owner $^{b}$ & 0 (Possession: 10) & Male & 60 \\
\hline P8 & Tenant & 2 & Male & 30 \\
\hline P9 & Tenant $^{c}$ & 3 & Male & 30 \\
\hline P10 & Tenant $^{\mathrm{a}}$ & 3 & Male & 40 \\
\hline P11 & Tenant $^{b}$ & 50 & Female & 50 \\
\hline P12 & Tenant & 1 & Female & 20 \\
\hline $\mathrm{P} 13$ & Tenant $^{\mathrm{a}}$ & 3 & Female & 40 \\
\hline P14 & Visitant & - & Female & 20 \\
\hline P15 & Visitant & - & Male & 30 \\
\hline P16 & Visitant & - & Female & 20 \\
\hline P17 & Visitant & - & Male & 30 \\
\hline P18 & Visitant & - & Male & 20 \\
\hline P19 & Visitant & - & Male & 30 \\
\hline P20 & Visitant & - & Female & 50 \\
\hline P21 & Visitant & - & Male & 60 \\
\hline
\end{tabular}

a: Building over 20 year, b: over 50 year. c:over 70 year.

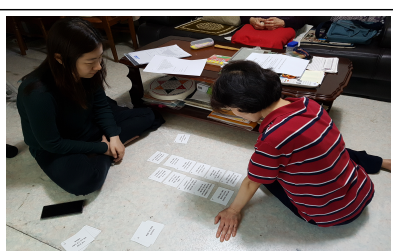

a: P1 Q Survey

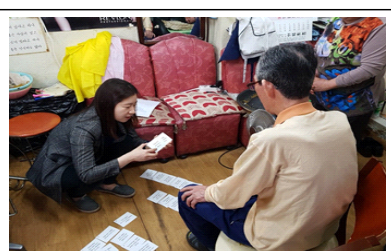

b: P11 Q Survey
Figure 3. Q Survey progress scene

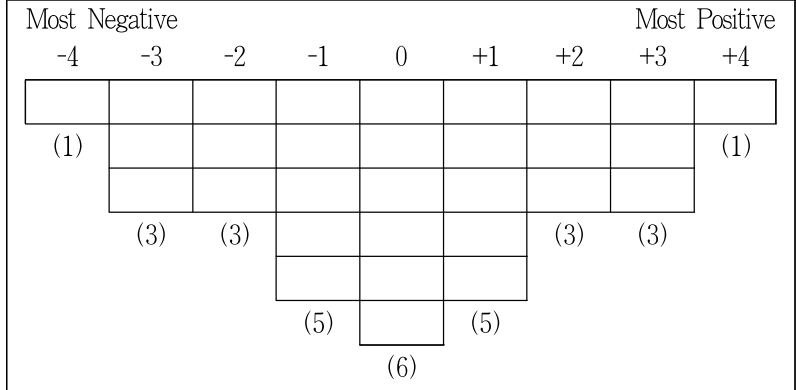

Figure 4. Q sample distribution $(n=30)$

\section{IV. 연구 결과}

\section{1. 인식유형의 형성}

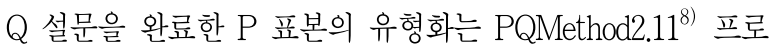
그램을 활용하였다. $\mathrm{Q}$ 유형 분석은 주성분 분석을 사용하고 베 리맥스(Varimax)로 회전하였담. 이후 고유치(Eigenvalue) 1.00 이상을 기준으로 산출된 결과와 설명변량을 고려하여 3 개의 유 형으로 분류하였다 ${ }^{10)}$. Table 6 은 주성분 분석 시 고유치와 설 명변량(Exp Var.)이다. 이 유형들은 총 변량의 약 $67 \%$ 를 설명 한다. 전체 연구대상자 21 명 가운데 유형 1 에 속한 사람은 13 명, 유형2는 5명, 유형3은 3명으로 분류되었으며(Table 7 참조) $\mathrm{Q}$

Table 6. Eigenvalue and cum variable

\begin{tabular}{c|c|c|c}
\hline & Factor 1 & Factor 2 & Factor 3 \\
\hline Eigenvalue & 8.6271 & 3.9720 & 1.6035 \\
\hline Exp Var. $\%$ ) & 38 & 18 & 11 \\
\hline
\end{tabular}

Table 7. Factor loading score

\begin{tabular}{c|c|c|c}
\hline & Type 1 & Type 2 & Type 3 \\
\hline P1 & 0.1090 & $0.7197^{*}$ & 0.3020 \\
\hline P2 & -0.1911 & 0.4597 & $0.7157^{*}$ \\
\hline P3 & 0.3036 & 0.2608 & $0.6753^{*}$ \\
\hline P4 & -0.0287 & $0.5886^{*}$ & -0.0560 \\
\hline P5 & -0.0438 & $0.8664^{*}$ & 0.2105 \\
\hline P6 & $0.7282^{*}$ & 0.1035 & 0.5315 \\
\hline P7 & -0.2652 & $0.7588^{*}$ & -0.0603 \\
\hline P8 & $0.7905^{*}$ & -0.2899 & 0.2645 \\
\hline P9 & $0.7349^{*}$ & -0.0544 & 0.3822 \\
\hline P10 & $0.7968^{*}$ & -0.3277 & 0.1303 \\
\hline P11 & 0.5363 & -0.2154 & $0.6819^{*}$ \\
\hline P12 & $0.6771^{*}$ & -0.5262 & 0.1632 \\
\hline P13 & -0.0478 & $0.8449^{*}$ & 0.0917 \\
\hline P14 & $0.8258^{*}$ & 0.1388 & 0.0961 \\
\hline P15 & $0.8533^{*}$ & -0.1054 & 0.1017 \\
\hline P16 & $0.6399^{*}$ & -0.0623 & -0.0003 \\
\hline P17 & $0.8148^{*}$ & 0.0401 & 0.0956 \\
\hline P18 & $0.7437^{*}$ & 0.0770 & 0.1549 \\
\hline P19 & $0.7693^{*}$ & -0.2446 & -0.1620 \\
\hline P20 & $0.8033^{*}$ & -0.1304 & 0.0284 \\
\hline P21 & $0.6274^{*}$ & 0.0955 & -0.4443 \\
\hline
\end{tabular}


Table 8. Q-sort values for each Q-statement

\begin{tabular}{|c|c|c|c|}
\hline & Type 1 & Type 2 & Type 3 \\
\hline Q1 & 4 & -1 & 0 \\
\hline Q2 & -1 & 1 & 1 \\
\hline Q3 & 2 & 0 & -1 \\
\hline Q4 & 0 & -1 & -3 \\
\hline Q5 & 0 & -1 & -1 \\
\hline Q6 & -4 & 0 & 0 \\
\hline Q7 & 1 & -1 & 1 \\
\hline Q8 & -2 & 2 & 2 \\
\hline Q9 & 3 & 1 & 0 \\
\hline $\mathrm{Q} 10$ & -1 & 1 & 1 \\
\hline Q11 & 2 & 0 & -1 \\
\hline Q12 & -3 & 1 & -2 \\
\hline Q13 & 2 & -4 & -2 \\
\hline Q14 & -3 & -1 & -3 \\
\hline Q15 & 3 & 1 & 2 \\
\hline Q16 & -3 & 0 & -4 \\
\hline Q17 & 3 & -2 & -2 \\
\hline Q18 & 1 & 2 & 1 \\
\hline Q19 & -2 & -2 & -3 \\
\hline Q20 & 1 & 0 & 2 \\
\hline Q21 & -1 & 3 & -1 \\
\hline Q22 & -1 & -3 & 0 \\
\hline Q23 & -1 & 2 & 0 \\
\hline Q24 & 0 & 0 & 1 \\
\hline Q25 & 0 & -3 & 3 \\
\hline Q26 & -2 & 3 & 0 \\
\hline Q27 & 0 & -3 & 3 \\
\hline Q28 & 1 & 3 & 4 \\
\hline Q29 & 0 & -2 & -1 \\
\hline Q30 & 1 & 4 & 3 \\
\hline
\end{tabular}

Table 9. Correlation between factor scores

\begin{tabular}{c|c|c|c}
\hline & 1 & 2 & 3 \\
\hline 1 & 1.0000 & -0.1705 & 0.3442 \\
\hline 2 & -0.1705 & 1.0000 & 0.3258 \\
\hline 3 & 0.3442 & 0.3258 & 1.0000 \\
\hline
\end{tabular}

진술문의 각 유형별 점수(Q-sort Value)는 Table 8과 같다. 이 때 각 요인은 같은 견해를 갖는 응답자의 집단을 의미하며 (Brown, 1980; Kim, 2016b), 각 유형에 해당하는 인원의 많고 적음은 중요하지 않다. 유형 간 상관관계를 검토한 Table 9에 서 가장 높은 수준이 0.34 이므로 ${ }^{11)}$ 유형별로 독립된 특성이 있 다고 판단된다.

\section{2. 유형별 특징 분석}

Q 방법론은 연구대상자의 자기준거적(self-reference) 가치, 견해 및 인식에 관한 것으로 해석적인 방법론으로 볼 수 있다 (Park et al., 2001). 양극단 값을 갖는 진술문의 경우, 각 요인 에 해당하는 구성원들이 강하게 동의하거나 반대하는 것을 의 미하기 때문에 요인의 특성을 해석하는 데 중요한 근거이다 (Brown, 1986; Kim, 2016b). 본 연구는 후암동 일본식 건물군 에 관한 연구대상자의 견해를 확인하기 위해 추출된 3 개의 유 형의 특성을 극단값 $(+4,+3,-3,-4)$ 의 진술문을 토대로 기술 하고, 풍부한 해석을 위하여 추가로 진행한 면접내용을 활용하 였다. 유형별 명칭은 양극단 진술문의 기반이 되는 근대문화유 산 가치를 중심으로 '사회문화 - 역사적 가치 결합형(유형 i )', '경제적 가치 중시형(유형 $\mathrm{ii}$ )', '사회문화 - 경제적 가치 결합형 (유형 iii)'이라 명명하였다.

\section{1) 유형 i : 사회문화 역사적 가치 결합형}

유형 i 에는 총 13 명이 포함되었고, 그중 후암동 주민은 5명 (소유자 1명, 임대자 4명), 방문자는 8명 모두가 해당하였다. 유형 i 은 후암동의 일본식 건물군에 대해 긍정적으로 반응하 는 집단으로 양극단 진술문에는 사회문화적, 역사적, 건축적 가 치가 나타났다(Table 10 참조). 이들은 일본식 건물군을 오랜 시간 축적된 문화 흔적으로 후암동의 대표 공간이자 한국의 역 사를 나타내는 장소라 판단하였다.

구체적으로 유형 $\mathrm{i}$ 은 후암동 건축물이 독특한 건축 재료가 사용된 근대 건축양식이고(Q9), 우리나라의 주거 변화의 살아 있는 자료 $(\mathrm{Q} 1)$ 라고 생각하였다. 이들은 후암동 일본식 건물군 에 대해 꽤 높은 배경지식을 갖고 있었는데, 특히 주민들은 '적 산가옥'이라는 단어부터 후암동의 일본식 건물군이 일본과 네 덜란드 양식 ${ }^{12)}$ 이 혼합이라는 사실도 이해하고 있었다. 또한, 응 답자 $(\mathrm{P} 10)$ 는 일제강점기 건물은 우리나라에 새로운 공간을 도 입한 것으로 해석할 수 있다고 하면서 한국의 대표 주거 형태 인 아파트 이전의 과도기적 형태가 아닐까 싶다고 말하였다. 이는 일제강점기 건물도 우리나라 역사의 흔적이라 여기는 생 각 $(\mathrm{Q} 6)$ 과 이어진다. 유형 $\mathrm{i}$ 의 응답자들은 후암동 일본식 건물 군은 광복 이후 불하(拂下) 정책을 통해 우리나라 사람들의 삶 의 터전이 되었고, 이 시간이 일본인의 거주기간보다 길다는 것을 강조하였다. 특히 응답자 2 명 $(\mathrm{P} 15, \mathrm{P} 16)$ 은 도리어 후암동 일본식 건물군은 일제강점기의 유산이라 할 수 없다면서 후암 동을 '시간의 중첩, '진짜 서울 같은 느낌', '오랜 삶의 모습' 등 으로 표현하였다. 그러므로 이들은 유명건축가가 지은 것이 아

Table 10. Top and bottom Q sentence of Type 1

\begin{tabular}{c|c|c|c|c|c|c|c|c}
\hline Value(Ranking) & -4 & -3 & -3 & -3 & +3 & +3 & +3 & +4 \\
\hline \multirow{2}{*}{ Q sentence } & Q 6 & Q 14 & Q 16 & Q 12 & Q 9 & Q 15 & Q 17 & Q 1 \\
\cline { 2 - 8 } & Historical & Socio-cultural & Socio-cultural & Architectural & Architectural & Socio-cultural & Socio-cultural & Historical \\
\hline
\end{tabular}


닌 후암동 일본식 건물들도 보존할 가치가 있다(Q12)고 여긴 다. 또한, 유형 1 은 부정적인 역사도 역사이고, 이러한 장소를 잘 남겨두어 역사교육의 장으로 활용해야 한다는 의견을 제시 하였는데, 사회적으로 잘못된 역사관을 만드는 요소가 아니라 는(Q14) 사회문화적 진술문과 연결된다.

유형 i 은 양극단 진술문에 사회문화적 가치 내용이 가장 많 이 포함된 집단이다. 이들은 일본식 건물들은 후암동을 이해하 는 데 도움을 주는 요소이지 $(\mathrm{Q} 17)$ 후암동 주민들의 자긍심을 저하하지 않는다고 $(\mathrm{Q} 16)$ 판단한다. 방문자 $(\mathrm{P} 14)$ 는 독특한 후 암동 건물들이 후암동만의 지역 색깔을 표현한다고 하였다. 또 다른 방문자 $(\mathrm{P} 17)$ 는 오랫동안 유지되었기 때문에 오히려 일본 식 건물군에 대한 주민들의 애착이 높을 것 같다고 하였는데, 실제로 유형 i 에 속하는 후암동 주민들은 비교적 오래 거주하 지 않았음에도 후암동 일본식 건물들에 대한 애착심을 강하게 드러냈다.

후암동 일본식 건물군에 대해 긍정적인 유형 $\mathrm{i}$ 은 전체 응답 자 가운데 가장 많은 수였으나, 방문자 8명 중 8명 전원이 속했 다. 후암동 주민이 5 명이 포함되었으나, 실제 건물 소유자가 아 닌 임대자가 4명 포함되었고, 소유자 1 인 역시 거주기간이 3년 이었다. 즉, 유형 i 은 외부인의 시각에 가깝다고 볼 수 있다.

\section{2) 유형 $\mathrm{ii}$ : 경제적 가치 중시형}

유형 ii에는 총 5명이 포함되었다. 이들은 모두 후암동 주민 으로 소유자 4 명, 임대자 1 명이다. 유형 ii는 후암동 일본식 건 물군을 강하게 부정한다. 양극단 진술문에는 경관적 가치와 사 회문화적 가치를 포함하고 있지만, 경제적 가치가 가장 많은 범위를 차지한다(Table 11 참조). 이들은 일본식 건물 유지비 용이 많이 들고 외관적으로도 지저분한 건물일 뿐이며, 관광자 원으로도 활용할 가치가 없는 골칫덩어리로 표현하였다.

구체적으로 유형 $\mathrm{ii}$ 는 건물이 오래 되어 유지보수 비용이 많 이 들기 때문에(Q30) 부수고 현대식 건물로 신축하는 것(Q26) 이 후암동에 이롭다고 생각한다. 실제 후암동 주민으로 구성된 유형 ii 응답자들은 낡은 건물의 불편함을 토로하였다. 얇은 벽 체와 단일 창은 단열 기능이 낮으므로 임대하기 위해서도 수리 를 해야만 하고(P5), 묵은 먼지와 곰팡이 등으로 인한 실제 거
주환경이 좋지 않아 경제적 여건이 나아지면 거주지를 옮기고 싶다는 의견(P13) 등이 있었다.

유형 ii는 오래된 일본식 건물군의 실제 거주인 외에도 방문 자에게 후암동을 지저분하게 보이게 하는 요소(Q21)이며, 이 국적인 분위기와 거리가 멀다고 생각한다 $(\mathrm{Q} 22)$. 응답자 $(\mathrm{P} 4$, $\mathrm{P} 7)$ 는 남산 주변이 전부 현대식 건물로 화려하게 개발된 것에 비해 상대적으로 일본식 건물군이 밀집된 후암동은 낙후되어 보기 싫은 경관으로 방치되었다고 평가하였다. 후암동 일본식 건물들이 이색적인 관광자원이 아니며 $(\mathrm{Q} 25)$ 일본식 건물을 구 매하고 싶지 않다는 의견(Q27)과 같은 맥락이다. 이들은 훌륭 한 경관이라면 벌써 많은 방문객이 있어야 하지만 그렇지 않고 $(\mathrm{P} 1, \mathrm{P} 7)$ 외부인들은 후암동에 일본식 건물군이 있다는 사실 도 모른다고 생각한다(P7, P4, P13) ${ }^{13)}$.

그런데도 유형 $\mathrm{ii}$ 가 일본식 건물을 소유하는 이유는 몇 년 전 부터 꾸준히 후암동 재개발에 대한 움직임이 시작되었고(P4) 용산공원으로 인해 약 3 년 전부터 부동산 가격이 지속해서 상 승하고 있기 때문이다(P4, P7). 따라서 이들은 재산권 행사에 문제가 생길 수 있는 근대문화재(지역)로 지정되는 것에 반대 한다(Q28). 연구자는 일본식 건물군을 활용하여 한국의 군산, 일본의 교토와 같이 상업 거리를 통한 부가수익에 대한 의견을 추가 질문을 하였다. 응답자는 내외부 보수 등 높은 초기비용 에 비해, 건물의 작은 규모와 주차공간 부족으로 많은 인원을 수용할 수 없어 수익성이 낮다는 의견(P7)과 도심부에 저층의 근대역사 공간은 현실성이 없다(P4) 등 경제적 가치에 대한 구체적인 판단 기준을 갖고 있었다.

\section{3) 유형 $\mathrm{iii}$ : 사회문화 · 경제적 가치 결합형}

유형 iii는 모두 후암동 주민(소유자 2명, 임대자 1명)이었다. 이들은 유형 $\mathrm{i}$ 과 마찬가지로 일본식 건물군에 대해 긍정적으 로 바라보면서도 일본식 건물의 거주환경에 대한 유형 ii 의 불 평을 동감한다. 그러나 유형 iii은 후암동에 대한 강한 애착으로 약간의 불편함을 감수할 수 있으며, 일본식 건물군을 통해 경 제적 이익을 기대한다. 양극단 진술문에서도 경제적 가치와 사 회문화적 가치가 강하게 나타났다(Table 12 참조). 경제적 가 치가 가장 강하게 나타났으나, 애착을 기반으로 한 활용을 기

Table 11. Top and bottom Q sentence of Type 2

\begin{tabular}{c|c|c|c|c|c|c|c|c}
\hline Score & -4 & -3 & -3 & -3 & +3 & +3 & +3 & +4 \\
\hline \multirow{2}{*}{ Q sentence } & Q 13 & Q 25 & Q 27 & Q 22 & Q 28 & Q 26 & Q 21 & Q 30 \\
\cline { 2 - 8 } & Socio-Cultural & Economical & Economical & Landscape & Economical & Economical & Landscape & Economical \\
\hline
\end{tabular}

Table 12. Top and bottom Q sentence of Type 3

\begin{tabular}{c|c|c|c|c|c|c|c|c}
\hline Score & -4 & -3 & -3 & -3 & +3 & +3 & +3 & +4 \\
\hline \multirow{2}{*}{ Q sentence } & Q 16 & Q 14 & Q 4 & Q 19 & Q 25 & Q 27 & Q 30 & Q 28 \\
\cline { 2 - 8 } & Socio-cultural & Socio-cultural & Historic & Socio-cultural & Economical & Economical & Economical & Economical \\
\hline
\end{tabular}


대한다는 점에서 사회적 가치 중시형으로 명명했다.

구체적으로 유형iii은 노후로 인한 유지보수 비용이 많이 들 고(Q30), 후암동이 근대문화재(지역)로 지정되면 재산권 행사 에 문제가 생길 수도 있다는 걱정을 한다(Q28). 그러나 이들은 근대문화재(지역) 지정에 부정적이지만은 않다. 살기에는 아주 편한 집은 아니나, 서울의 모든 곳이 아파트 단지로 변화하는 것에 더욱 반대하기 때문이다(P11). 서울 도심에서 마을의 모 습을 가진 후암동은 “서울 같지 않은 서울"이라고 비유하며, 특별한 장소성을 강조한다(P2). 이는 후암동과 관련된 역사적 사건이나 인물들이 있으며 $(\mathrm{Q} 4)$, 후암동의 일본식 건물을 보 존 · 활용하는 것은 제대로 된 역사를 알 수 있는 장소라는 생 각(Q14)과 이어진다. 이들은 용산미군기지(구, 일본군 주둔지) 와 후암동의 관계를 강조하며(P2, P3, P11), 후암동은 역사적 으로 중요한 장소라는 생각을 공유한다. 유형iii에게 일본식 건 물군은 자긍심을 저하하는 공간이 아닌(Q16) 역사의 중심이다.

유형 iii은 후암동은 사람들이 함께 사는 마을이라는 것을 강 조하며, 후암동을 사람이 살고 있지 않은 세트장 같다는 의견 을 반대한다(Q19). 이는 유형 $i i$ 의 응답자들이 모두 20년 이상 후암동에서 거주하였던 사람들로 후암동을 본인의 청춘(P11), 성장(P3)공간이자 증거로 생각하였다. 그 때문에 이들은 최근 외지인의 후암동 건물 매매가 많아지는 분위기에 부정적이다. 외지인들은 단순히 투기목적으로 후암동 건물을 구매하기 때 문에 오랜 시간 유지해온 후암동의 문화와 풍경은 물론이고, 각 건물 존폐를 걱정해야 하는 상황이라고 말하였다(P11).

유형iii은 가능하다면 후암동 일본식 건물군을 구매하고자 한다(Q27). 이들은 앞서 언급한 것처럼 외지인보다 본인들이 구매하였을 때 지역색을 잘 유지하기에 바람직하다는 생각과 더불어 자신들에게 익숙한 풍경인 일본식 건물군이 외부인들 에게는 매력적인 경관임을 이해하기 때문이다. 실제로 응답자 는 몇 년 전부터 후암동을 방문하는 젊은 층이 늘어나는 것을 몸소 경험하였고(Q25), 노인 인구가 많은 후암동에 젊은 층의
유입을 굉장히 긍정적으로 여겼다(P11). 다만, 30대인 응답자 (P3)는 SNS상에서 후암동의 상점들에 관한 언급이 많지만 각 상점의 음식 혹은 상품에 집중된 것에 안타까움을 표하였고, 응답자(P2)는 주말에만 이루어지는 단발성 방문이 아닌 후암 동의 지속적인 관광을 위한 방안이 필요하다는 의견을 제시하 였다.

\section{4) 인식유형 간 특성 비교}

연구의 결과를 토대로 유형별 특징을 비교하면 다음과 같다 (Table 13 참조). 유형 i 은 사회문화적 가치가 양극단 진술문 의 $50 \%$ 로 가장 강하게 드러났고, 역사적, 건축적 가치를 중요 시하였다. 이들은 후암동 일본식 건물군을 후암동을 상징하는 공간이자 중첩된 한국의 역사를 느낄 수 있는 장소로 인식하였 다. 유형 $\mathrm{i}$ 에는 후암동에 거주하지 않는 방문자 전원이 포함되 었고, 유형 i 에 해당하는 주민도 거주기간이 짧았다는 점에서 외부인이자 장소 소비자의 시각으로 판단할 수 있다.

유형 ii 는 경제적 가치를 양극단 진술문의 $62.5 \%$, 경관적 가 치를 $25 \%$ 로 중요시하였다. 이들은 후암동 일본식 건물군을 유 지관리 비용이 많이 드는 지저분한 건물이고, 활용 가치도 없 는 골칫덩어리로 인식하였다. 유형 ii 는 모두 후암동 거주민으 로 구성되었고, 내부인이자 장소 공급자의 시각이라 할 수 있다.

유형iii은 유형 ii 와 함께 경제적 가치가 양극단 진술문의 $50 \%$, 사회문화적 가치가 $37.5 \%$ 로 강하게 드러났다. 이들은 후 암동 일본식 건물군을 본인의 청춘과 성장 과정이 담긴 추억의 공간이며, 서울에서 보기 힘든 경관을 갖고 있어 외부인에게 매력적인 공간으로 인식하였다. 유형 iii은 유형 ii 와 마찬가지로 모두 후암동 거주민으로 구성되어 내부인이자 장소 공급자의 시각이다.

각 유형은 중시하는 근대문화유산 가치에 따라 지향하는 후 암동 모습도 달랐다. 유형 $\mathrm{i}$ 은 후암동의 일본식 건물군이 그대 로 보존되고, 박제된 관광지가 아닌 일상을 느낄 수 있는 마을

Table 13. Recognition type synthesize

\begin{tabular}{|c|c|c|c|c|}
\hline \multicolumn{2}{|c|}{ Type } & $\begin{array}{l}\text { Type i : Socio-cultural } \\
\text { historical value type }\end{array}$ & Type ii : Economical value type & $\begin{array}{l}\text { Type iii: Economical } \\
\text { socio-cultural value type }\end{array}$ \\
\hline \multirow{2}{*}{$\begin{array}{c}\text { Modern } \\
\text { cultural } \\
\text { heritage } \\
\text { value }\end{array}$} & 1 & Socio-cultural & Economical & Economical \\
\hline & 2 & Historical / architectural & Landscape & Socio-cultural \\
\hline \multicolumn{2}{|c|}{$\begin{array}{l}\text { Representative } \\
\text { group }\end{array}$} & Outsider (place consumer) & \multicolumn{2}{|c|}{ Insider (place provider) } \\
\hline \multicolumn{2}{|c|}{$\begin{array}{l}\text { Japanese-style } \\
\text { building group }\end{array}$} & $\begin{array}{l}\text { Space that symbolizes Huam-dong } \\
\text { Place to feel the overlapping history }\end{array}$ & $\begin{array}{l}\text { Maintenance expensive messy building } \\
\text { Worthless building }\end{array}$ & $\begin{array}{l}\text { Memory space of youth and growth } \\
\text { attractive space for outsiders }\end{array}$ \\
\hline \multirow{2}{*}{\multicolumn{2}{|c|}{ Orientation }} & Preservation & Redevelopment (urbanization) & Utilization (continuous tourism) \\
\hline & & $\begin{array}{l}\text { Space for everyday life and a modern } \\
\text { cultural space }\end{array}$ & Modern dwellings to live in & $\begin{array}{l}\text { A modern cultural (tourist)destination where } \\
\text { the culture of Huam-dong is maintained }\end{array}$ \\
\hline
\end{tabular}


경관의 지속을 바란다. 유형 $\mathrm{ii}$ 는 후암동이 살기 좋은 현대식 주거지로 전면 재개발이 되기를 바라며, 유형 iii은 일본식 건물 군을 후암동만의 문화가 유지된 관광지로 활용하여 경제적 이 익을 창출하기를 바란다. 각 유형의 인식 차이는 근대문화유산 가치의 충돌로 이해할 수 있고 이는 갈등으로 이어질 수 있다.

유형 ii와 유형 iii의 응답자는 모두 후암동 거주자로 경제적 가치를 가장 중요시하나, 후암동 일본식 건물군에 대한 인식에 서 큰 차이가 나타났다. 유형 ii 는 살기 불편한 일본식 건물군 을 제거하고 현대식 건물로 신축하여 경제적 이익을 얻고자 하 지만, 유형iii은 불편을 감수하더라도 후암동의 풍경을 유지하 여 마을 관광 수익을 얻고자 한다. 이러한 차이가 나타나는 원 인을 사회문화적 가치에서 찾아볼 수 있다. 유형 $\mathrm{ii}$ 는 유형 $\mathrm{ii}$ 보다 후암동 거주기간이 짧았다(Table 5 참조). 유형 ii는 한 명을 제외하고는 거주기간이 10년 이하이고, 그중 한 명은 후 암동 거주 경험이 없는 소유자이다. 반면 사회문화적 가치를 중시하는 유형 $\mathrm{iii}$ 은 20년 이상 거주하였으며, 마을 공동체에 참 여하고 있었다 ${ }^{14)}$.

유형 i 과 유형 $i i i$ 의 인식 차이에서는 소비자와 공급자 간 가 치충돌로 이해된다. 유형 iii은 늘어나는 후암동 방문객 때문에 일본식 건물군을 경제적으로 활용할 가치가 있다고 판단한다. 그러나 외부인이자 장소 소비자인 유형 $\mathrm{i}$ 은 후암동의 상업화 를 원하지 않고 현재와 같이 마을의 모습을 유지하길 바란다. 이처럼 근대문화유산의 경제적 활용에 관한 소비자와 공급자 간 가치충돌은 다른 지역에서도 쉽게 관찰된다. 상업화, 관광화 에 의존하는 다수의 근대문화유산은 시간이 흐를수록 소비자 의 외면을 받는다.

유형 i 과 유형 iii은 후암동 일본식 건물군을 근대문화유산으 로 판단하였으나, 유형 ii는 근대문화유산의 인정은 완전한 보 존으로 재산권 행사가 제한된다는 점에서 반대한다. 한편, 유형 $\mathrm{i}$ 은 후암동 일본식 건물군을 근대문화유산으로는 인정하나, 유산을 박제된 보존으로 오해하는 경향을 보였다. 유형 $\mathrm{i}$ 의 응 답자 $(\mathrm{P} 17)$ 는 서울시 종로구 돈의문 박물관 마을을 예로 들면 서 근대문화유산의 인정으로 거주민의 생활문화가 사라질 수 있음을 걱정하였다. 이들은 일본식 건물군을 한국 주거공간의 변천을 볼 수 있고, 현재도 변화하는 중이라는 생각에서 보존 해야 할 '유산'이라기보다는 발전시켜 나가야 하는 '생활문화' 라는 의견을 제시하기도 하였다. 이러한 근대문화유산에 대한 인식은 현재까지 우리나라 문화유산의 종류와 범위가 굉장히 한정적이었고 보존과 활용의 다양성이 없었음을 의미한다.

거주자인 유형 $\mathrm{ii}$ 와 유형 $\mathrm{iii}$ 의 $\mathrm{Q}$ 설문을 통하여 후암동 일본 식 건물군의 낙후된 거주환경을 알 수 있었다. 반면 외부인인 유형 i 은 후암동 일본식 건물군의 거주환경을 알지 못했고, 근 대 마을 모습과 한국 주거의 변천을 볼 수 있는 후암동의 풍경 이 유지되기를 바란다. 근대문화유산으로 후암동 일본식 건물 군을 보존 활용하기 위해서는 사유재산에 대한 고려와 낙후
된 생활환경의 개선이 선행되어야 할 것이다. 생활환경을 높이 면서도 근대문화적 가치가 살아있는 공간에 대한 전문가들의 노력이 요구된다. 소유자가 선택할 수 있는 근대건축물 활용 방안이 다양해져야 하며, 살아있는 유산(Living Heritage)으로 지속할 방법이 마련되어야 한다.

\section{V. 결론}

본 연구는 $\mathrm{Q}$ 방법론을 이용하여 후암동 일본식 건물군에 대 한 이해관계자의 근대문화유산 가치 인식을 분석하였다. 연구 의 결과, 이해관계자의 인식은 3 가지 유형으로 도출되었고, 유 형별로 중시하는 근대문화유산 가치에 따라 후암동 일본식 건 물군에 대한 태도와 지향점이 달랐다. 유형 i :사회문화 - 역사 적 가치 결합형은 일본식 건물군을 가장 긍정적으로 인식하는 집단으로 일본식 건물군을 후암동의 지역 정체성이자 주거공 간으로서의 문화가 역사가 담긴 것으로 이해하였다. 유형 ii : 경 제적 가치 중시형은 일본식 건물군을 유산적 가치보다 보전으 로 인한 경제적 손실을 우려하는 집단으로 근대문화유산에 대 한 부정적 인식을 갖고 있다. 유형 $\mathrm{ii}$ :사회문화 - 경제적 가치 결합형은 근대문화유산으로서의 가치를 경제적으로 활용하고 자 하는 집단으로 근대문화유산을 단순히 문화재가 아닌 상품 화 할 수 있는 대상으로 인식하고 있었다. 인식유형 간 차이는 근대문화유산 가치의 충돌로 이해할 수 있고, 이는 갈등으로 이어질 수 있다. 본 연구결과에서는 일본식 건물군의 경제적 가치에 대한 평가, 사회문화적 가치 인정과 공유, 장소 소비자 와 공급자 간의 가치충돌 등이 관찰되었다. 이는 $\mathrm{Cho}(2001)$ 가 말한 근대문화유산의 본질인 '가치의 상충성'으로 이해되며, 이 들 간의 가치충돌이 해결될 때 후암동 일본식 건물군에 대한 건강한 활용이 가능할 것이다. 연구의 결과를 바탕으로 제언하 자면, 본 연구의 대상지인 후암동은 서울 안에 위치하고 일상 거주공간인 근대문화유산이라는 점에서 사유재산에 대한 고려, 낙후된 생활환경 개선, 근대문화유산 보존과 활용에 대한 홍보 가 필요하다고 판단된다.

본 연구는 향후 일본식 건물 밀집 지역에 대한 보존 및 활용 의 기초자료 구축과 갈등 해결을 통한 지속 가능한 면적 문화 유산 활용의 실마리를 제시하였다는 의의가 있다. Q 방법론을 사용한 본 연구는 서울 중심부에 밀집된 일본식 건물군의 인식 을 심층적으로 접근하였다. 특히 근대문화유산에 직접권리가 있는 이해관계자를 연구대상으로 했다는 점에서 본 연구가 갖 는 의미는 크다. Q 방법론은 주관성 연구로써 연구결과를 일반 화할 수 없다는 한계를 가진다. 그러므로 본 연구로 확인한 쟁 점과 인식유형은 향후 후암동 일본식 건물군에 관한 객관적 연 구의 토대가 되어야 할 것이다. 일본식 건물군은 곳곳에 다양 한 사례가 있으나, 지역마다 상황과 조건이 다르다. 따라서 양 
적 연구와 제도 수립 이전에 본 연구와 같이 각 대상지를 깊게 이해하는 과정이 필요하다. 또한, 국내 일본식 건물 밀집 지역 대한 일반적인 갈등 양상을 파악하기 위해서는 향후 다양한 지 역과의 비교 연구가 필요하며, 이는 후속 연구로 남긴다.

주 1. 러일전쟁 발발 후 1904 년 2월 23일 한일의정서를 바탕으로 일본군 은 한국에 주둔하게 되었고, 1908 년 용산에 일본인 병영이 완공, 현 재에는 용산 미군기지로 사용되고 있다.

주 2. SBS(2019), Financial news(2019), Herald Economic(2019), JoongAng Ilbo(2019) 등 다양한 매체에서도 후암동의 일본식 건물군에 관한 찬성과 반대의 의견에 대해 논하였다.

주 3. $\operatorname{Kim}(2016 \mathrm{~b})$ 은 Q 방법론의 객관적 방식은 배경적 변수 간 상관관계 와 요인 파악하는 R 방법론과 달리 사람 간의 상관관계·요인을 분 석하는 것으로 차이가 있다고 말한다.

주 4. Park(2003)은 역사적 도시에서 우리가 보고자 하는 것은 '역사적 층'이고, 역사적 건축물에 대한 보전은 과거의 역사가 현재 사람들 에 의해 경험되며, 역사적 연속성을 부여받는다고 설명한다.

주 $5.5 \times 2$ 구조는 근대문화유산 가치(5) × 긍정과 부정 (2)을 의미한다.

주 6. Q 방법론은 단일표본 연구도 진행 가능할 정도로 $(\mathrm{Kim}, 2010 \mathrm{a})$ 소 표본의 원칙(small Sample doctrine)을 따른다(Cho, 2018).

주 7. 연구대상자와의 면접은 $\mathrm{Q}$ 설문과 추가 질문을 포함하여 최단 약 25 분에서 최장 약 50 분까지 진행되었다.

주 8. 본 연구에서 활용한 통계 프로그램인 $\mathrm{PQMethod}$ 는 국제 주관성 학 회(qmethod.org)에서 추천하는 프로그램이자 모든 운영체제에서 활용 가능한 공개 소프트웨어이다. Peter Schmolck에 의해 유지·보수 되고 있으며, Kent State University의 John Atkinson의 FORTRAN 코드를 기반으로 한다.

주 9. 베리맥스(Verimax) 회전은 변수 간 공통점을 찾아내어 하나의 요 인으로 묶는 요인회전 방식 중 하나이다. 베리멕스는 변수의 수를 최소화하는 직교 회전 방법이다.

주 10. 고유치 1.00 이상을 기준으로는 4 가지 유형이 나왔으나, 단 1 명만으 로 구성된 유형이 존재하여, 3 개의 유형으로 구분하였다.

주 11. Table 7은 각 유형이 얼마나 상관성이 높은가를 보여준다. 가장 높 은 수치였던 유형 1 과 유형 3 의 상관성이 0.34 라는 의미는 약 $34 \%$ 가 관련있음을 의미한다. $\mathrm{Q}$ 방법론을 사용한 선행연구를 살펴보면 $\mathrm{Ryu}(2016 \mathrm{~b})$ 는 가장 높은 상관성이 49.5\%, Park and Shin(2014)은 $26.0 \%$ 라는 점에서 본 연구의 인식 유형별 최대 상관성 수치인 $34 \%$ 는 3 가지 유형별 특성에 대한 유의미한 설명력을 갖는다고 판단할 수 있다.

주 12. 주민 1 명의 경우 ‘네덜란드' 양식을 직접 언급하였고, 나머지 3 명은 '서양으로 표현하였다.

주 13. $\mathrm{P} 1$ 은 한국인은 방문하지 않으나 삼광초등학교(당시, 삼판초)를 졸 업한 일본인이 찾아오는 경우는 꽤 많다고 진술하였다. 실제로 임 대자인 P13은 후암동에 이사를 올 때 일본식 건물들이 있는 곳인지 도 몰랐다고 한다.

주 14. P2는 자녀를 성장시키는 동안 자녀의 친구 부모와의 모임이 현재까 지 지속하고 있다. P3과 P11은 후암동에서 초.중·고등학교를 거쳐 동창 모임이 있다. $\mathrm{P} 3$ 는 현재 동창생들과 함께 거주하고 있으며, $\mathrm{P} 11$ 의 경우 동창 이외에도 금요일마다 성당 모임에 참석한다.

\section{References}

1. Brown, S. R.(1980) Political Subjectivity: Applications of Q Methodology in Political Science. New Heaven, CT: Yale University Press.

2. Cho, I. S. (2012) A Study on the Improvement of Publicness with the Regeneration of Historic Buildings. M. D. Dissertation, Chonnam National University.

3. Cho, I. S. (2016a) A Study on the Remodeling Strategies of Historical
Building and the Cognitive Evaluation. Ph. D. Dissertation, Chonnam National University.

4. Cho, J. A.(2018) A study on subjectivity of college students on contraception. Journal of KSSSS 43(0): 27-45.

5. Cho, M. R.(2001) Articles: A study on government - Citizen networks for the preservation of modern cultural heritages. Commnity Development Review 26(1): 187-200.

6. Cho, S. S.(2016b) A study on possibility of eco-museum composition using rural modern cultural heritage. Jouranl fo Museum Scholarship $30(0): 65-89$.

7. Choi J. N., and S. H. Lee(2013) Modern cultural heritage value and utilization of archiving data in Daejeon. Journal of Digital Convergence $11(7): 1-7$.

8. Dan, S. H. and Y. J. Choi(2017) The complex library planning using of modern cultural heritage. Journal of the Institute of Constructional Technology 36(2): 43-50.

9. Financial news(2019) Japanese style building. January 20, 31.

10. Herald Economic(2019) 100 Years of Japanese-Style Building ... Become a Consumption Space in Historical Space. February 28, 1.

11. Hong, S. J.(2008a) The formation and transformation of urban identity with special reference to discourses on modern cultural heritage. The Journal of Korean Studies 19: 77-106.

12. Hong, S. Y.(2008b) Study on Method to Regeneration Following the Conservation Value of Modem Architectural. Ph. D. Dissertation, DongA University.

13. Hong, S. Y.(2019) An explorative study of perception on environmental awareness of elementary school students using Q methodology. Journal of the Association of Korean Geographers 8(2): 139-154.

14. Je, J. S. and B. H. Song (2017) Modern cultural heritage in Busan and issues of historical awareness. Hangdo Busan 33(0): 141.

15. Jeon, S. J.(1999) A Study On Conservation of the Modern Buildings to exist actually in KangKyoung. M. D. Dissertation, Chungnam National University.

16. JoongAng Ilbo(2019) The first town under Mt.Nam in Seoul, The alleyway where time is also scattered. March 12, A20.

17. Jung, Y. S. (2005) A Study on the Application to Criteria for Conservation of Modern Buildings. M. D. Dissertation, Dongeui National University.

18. Kim, G. H.(2017) An Economic Valuation of Preserving Modern Architecture by Contingent Valuation Method. M. D. Dissertation, Seoul National University.

19. Kim, I. H.(2016a) The study on modern cultural sites of Shin-hang Li, Asan. Journal of Humanities and Science at Soonchunhyang University 35(4): 5-30.

20. Kim, S. E.(2010a) Theory and philosophy of Q methodology. Korean Society and Public Administraction 20(4): 1-25.

21. Kim, S. E.(2016b) Q Methodology \& Social Siences. Seoul: JomteongMunhwa.

22. Kim, S. J. and Y. T. Kim(2012). A study on the criteria for conservation value of modem architecture as culture heritage. Joumal of the Regional Association of Architectural Institute of Korea 14(1): $1-8$.

23. Kim, S. K.(2010b) Integrated Use of Modern Cultural Heritage in Pedestrian Network Planning of Ganggteong-eup. M. D. Dissertation, Seoul National University.

24. Lee, G. G.(1996) A Study on the Criteria for Preservation of Existing Buildings. M. D. Dissertation, Konkuk University.

25. Lee, H. M.(2003) Present Situation Examination Study for Conservation and Reuse of a Modem Architecture: Focused on the Registry Cultural Assets, M. D. Dissertation, Hongik University. 
26. Lee, H. S.(2011) Research articles: The analysis of relationships between the residents 'The community attachment and their perceptions on modern cultural heritage. Journal of Tourism Sciences 35(10): 329-345.

27. Lee, J. H. and M. J. $\operatorname{Kim}(2011)$ A study for estimating the preservation value of heritage tourism resource by a double-bound contingent valuation method. Journal of Tourism Management Research 15(4): 223-246.

28. Lee, K. H. and J. I. Park(2018) Modern cultural heritage utilization using historial maps and satellite pictures. Journal of Korean Dance 40: $117-133$.

29. Lee, S. J.(2000) Conservation and Restoration of Modern Architecture as Cultural Properties in Korea. M. D. Dissertation, Chongju University.

30. Oh, M. J. and K. E. Cho(2017) Examining the relationships among interpretation program for visitors, perceived authenticity, attitudes towards conservation of heritage, and perception of tourism invigoration at cultural heritage sites. International Journal of Tourism and Hospitality Research 31(7): 48-66

31. Ok, S. S. and H. J. Park(2011) Value of modern cultural heritage using contingent value method and real option approach: The study of Seoul City Hall case. Review of Culture \& Economy 14(2) : 53-74.

32. Park, G. S.(2003) Study on the Composition Scheme for Conservation Guidance of Modern Architecture in Korea. Ph. D. Dissertation, Myongji University.

33. Park, H. S., S. J. Lee, K. H. Park and E. G. Chang(2010) Conflict Management in Spatial Development Projects. Anyang: Korea Research Institute for Human Settlements.

34. Park, J. H. and K. J. Shin(2014) The types of experts' consciousness for the conservation and utilization of modern architecture. Journal Korea Society of Visual Design Forum 42(0): 307-318.

35. Park, J. M. and J. S. Sung(2013). A study on the value criteria and relative importance for conservation of modern cultural heritage.
Journal of Korean Institute of Landscape Architecture 41(1): 12-20.

36. Park, K. K., H. J. Ju and O. I. Kim(2001) Analyzing the perception types regarding whistle-blowing within the organization: An application of $\mathrm{Q}$ methodology. Korean Public Administration Review 35(1): $109-125$

37. Randall M.(2002) Assessing Value in Conservation Planning: Methodological Issues and Choices. In Assessing the Values of Cultural Heritage. 5-30. Los Angeles: The Getty Conservation Institute.

38. Ryu, B. S.(2016a) Modern cultural heritage and history of Gunsan. National University Library 34: 5-20.

39. Ryu, J. S.(2016b) The News Perception of Journalists and News Users in Digital Media Age based on Q Methodology and Depth Interview. Ph. D. Dissertation, Sung Kyun Kwan University.

40. SBS(2019) Newstory 220, An uncomfortable heritage. February 16.

41. Seoul Museum of History(2016) Huam-dong:the History of Duk-tuk Rock, Life in a Cultural House. Seoul:Seoul Museum of History.

42. Son, E. S. and J. H. Pae(2018) Conflicts between the conservation and removal of the modern historic landscapes. Journal of the Korean Institute of Landscape Architecture 46(4): 21-35

43. Song, Y. and J. S. Kim(2012) Valuing of cultural heritage using contingent valuation method. Journal of Tourism and Leisure Research 24(2): 253-267

44. Song, J. Y. and N. J. Kim(2018) The effect relationship between objective authenticity, experience, existential authenticity and satisfaction of modern cultural heritage site. International Journal of Tourism Management and Sciences 33(5): 48-66.

45. Whang, S. M and E. H. Choe(2002) Q-methodology and theory. Journal of KSSSS 7(0): 4-26.

46. Yang, E. J.(2012) Changes of Conservation Plans for a Historic City Center in Gunsan-Based on Content Analyses of Gunsan City Plans, M. D. Dissertation, Seoul National University.

Received : 23 September, 2019

Revised : 23 October, 2019

03 December, 2019

17 December, 2019

(1st)

(2nd)

Accepted : 17 December, 2019

(3rd)

4인익명 심사필 